\title{
Organometallic analogues of tamoxifen: Effect of the amino side- chain replacement by a carbonyl ferrocenyl moiety in hydroxytamoxifen
}

Anh Nguyen, Siden Top, Anne Vessières, Pascal Pigeon, Michel Huché, Elizabeth A. Hillard, Gérard Jaouen *

Laboratoire de Chimie et Biochimie des Complexes Moléculaires, UMR CNRS 7576, Ecole Nationale Supérieure de Chimie de Paris, 11 rue Pierre et Marie Curie, F-75231 Paris Cedex 05, France

\begin{abstract}
Since the widely prescribed selective estrogen receptor modulator (SERM) tamoxifen encounters growing cases of resistance in long-term treatments, alternative drugs with different therapeutic scopes have to be developed. Many investigators have modified the triphenylethylene scaffold, but very few have changed its amino side chain, essential for the antiestrogenic activity. For the first time, a lipophilic and stable organometallic entity, $\mathrm{OCH}_{2} \mathrm{CO}-\left[\left(\eta^{5}-\mathrm{C}_{5} \mathrm{H}_{4}\right) \mathrm{FeCp}\right]$, has replaced this key functional side chain, while keeping a good affinity for the estrogen receptor and an antiproliferative activity on cancer cells (MCF-7 and PC-3). Its mechanism of action is likely to be different from the antihormonal pathway followed by hydroxytamoxifen, and from the cytotoxicity observed for the ferrocifens.
\end{abstract}

Keywords: Bioorganometallic chemistry; Ferrocene; Breast cancer; Tamoxifen; SERM

\section{Introduction}

Breast tumours are generally classified into two types: those defined as hormone-dependent (2/3 of cases), in which the estrogen receptor is present in tumour cells (ER+), and those defined as hormone-independent (1/3 of cases), in which the estrogen receptor is not detected 
(ER-). In the case of ER+ tumours, the selective estrogen receptor modulator (SERM) tamoxifen is widely used to treat hormone-dependent breast cancer [1]. The antiestrogenic effect of its active metabolite, hydroxytamoxifen (Chart 1), is primarily attributed to its competitive binding to Estrogen Receptor $\alpha(\mathrm{ER} \alpha)$ and to its amino side chain $\mathrm{O}\left(\mathrm{CH}_{2}\right)_{2} \mathrm{~N}\left(\mathrm{CH}_{3}\right)_{2}$ [1a]. The X-ray structure of the LDB (ligand binding domain) of ER $\alpha$, crystallized with 4-hydroxytamoxifen, has shown that this basic side chain induces a stabilizing interaction with the Aspartate 351 residue (Asp 351) of ER $\alpha$ [2]. This interaction prevents the association of Helix 4 with Helix 12, impeding the recruitment of specific coeffectors and co-activators.

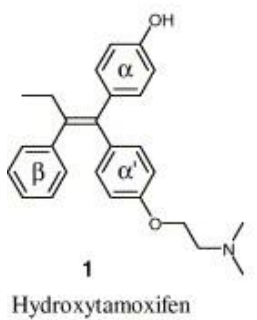

Hydroxytamoxifen

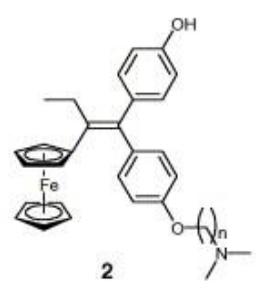

Ferrocifens with $\mathrm{n}=2,3,4,5$
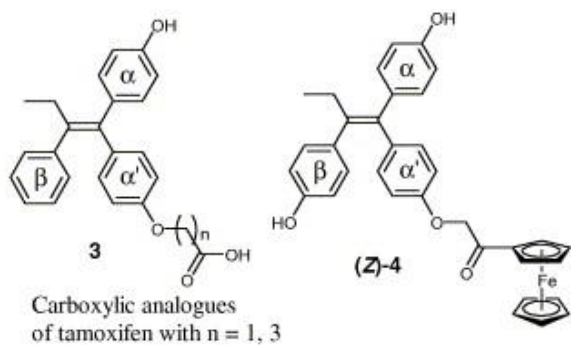

Chart 1.

However, in addition to its inefficacy against ER- tumours, one-third of ER+ tumours do not respond satisfactorily to administration of tamoxifen [1b]. Moreover, long exposure to the same drug often leads to a resistance phenomenon. For these reasons, many new molecules structurally related to the popular hydroxytamoxifen have been thoroughly screened, in order to obtain different therapeutic effects [1], [3], [4]. Since modification of substituents on the alkyl amine of the key side chain $-\mathrm{O}\left(\mathrm{CH}_{2}\right)_{2} \mathrm{~N}\left(\mathrm{CH}_{3}\right)_{2}$ has demonstrated the importance of the nitrogen atom in the antiestrogenic potency [1c,1d,3], only a few researchers have attempted to replace this functional group. The substitution of the amino side chain by a carboxylic acid side chain by Ruenitz et al. (compound $\mathbf{3}$ in Chart 1) was the only important estrogen antagonist example found so far [4]. In this case, the elongation of the chain length (to $n=3$ ) in $\mathbf{3}$ is crucial to observe a potent antiproliferative effect on hormone-dependent MCF-7 breast cancer cells. Indeed the carbonyl of the carboxylic acid may also interact with Asp 351, but it is not obvious that this interaction is the key to the antiproliferative activity of compound $\mathbf{3}$. 
We have previously shown that some ferrocenyl derivatives of hydroxytamoxifen (ferrocifens, 2) (Chart 1), obtained by substituting the $\beta$-phenyl ring of hydroxytamoxifen by a ferrocenyl unit, exhibit a strong antiproliferative effect on both hormone-dependent (ER $\alpha+)$ and hormone-independent breast cancer cells [5]. Thus, we demonstrated for the first time that the cytotoxic activity of tamoxifen can be potentiated by an organometallic substituent. We postulated, as to mechanism, the generation of ferricinium ion that may engender a Fentontype reaction [6], or the in situ generation of a quinone methide species, assisted by the ferrocenyl group [7]. Other series of organometallic derivatives were also prepared to probe the cytotoxicity of the ferrocenyl group on breast cancer cells [8]. In order to elucidate the activity of ferrocenyl derivatives and find new compounds with different activity, we propose now to study compound 4 which is characterized by the replacement of the $-\mathrm{O}\left(\mathrm{CH}_{2}\right)_{2} \mathrm{~N}\left(\mathrm{CH}_{3}\right)_{2}$ side chain by a stable and lipophilic ferrocenyl group $-\mathrm{OCH}_{2} \mathrm{CO}-\left[\left(\eta^{5}-\mathrm{C}_{5} \mathrm{H}_{4}\right) \mathrm{FeCp}\right]$ (Chart 1). Its activity may be very interesting because, in contrast to ferrocifens and tamoxifen, $\mathbf{4}$ does not have the antiestrogenic amino side chain, and the ferrocenyl group cannot assist the production of quinone methide. In addition, this ferrocenyl chain is a neutral group in contrast to the basic nature of the amino chain of tamoxifen and to the acidic nature of the carboxylato chain of $\mathbf{3}$. We describe now the synthesis of $\mathbf{4}$ and the results on its antiproliferative activity against cancer cell lines MCF-7 and PC-3.

\section{Results and discussion}

\subsection{Synthesis}

The synthetic pathway of $\mathbf{4}$ is shown in Scheme 1. We have found that the McMurry coupling reaction is very effective for the synthesis of alkene organometallic derivatives [5,9]. This coupling reaction is also suitable for the synthesis of $\mathbf{4}$. The reaction starts from the crosscoupling between 4-hydroxypropiophenone and 4,4'-dihydroxybenzophenone and is followed by a Williamson-type alkylation reaction. For this reason, all phenols that are not involved in the alkylation reaction must be first protected. Gauthier et al. have shown that the protection of the phenol functionalities can be achieved by using a pivaloate group as a protecting group [10]. Thus, 4-hydroxypropiophenone and 4,4'-dihydroxybenzophenone were first transformed into their protected forms, 5 and 6 respectively. McMurry coupling of 5 with $\mathbf{6}$, using $\mathrm{TiCl}_{4} / \mathrm{Zn}$ in THF, gave alkene $\mathbf{8}$ as a mixture of $Z$ and $E$ isomers in $67 \%$ yield. Chloroacetylferrocene 7 was prepared by alkylation of ferrocene with chloroacetyl chloride using a Friedel-Crafts reaction. Addition of $\mathbf{7}$ to the monopotassium salt of $\mathbf{8}$, obtained from the reaction with $\mathrm{KH}$, produced 9 in $41 \%$ yield. Finally, refluxing of 9 with $\mathrm{NaOH}$ in 
$\mathrm{H}_{2} \mathrm{O} / \mathrm{THF}$ for $6 \mathrm{~h}$ gave 4 as a mixture of $Z$ and $E$ isomers in $72 \%$ yield. The separation of the $Z$ isomer from the $E$ isomer was only achieved with preparative HPLC. Only the $(E)$ isomer gave crystals of sufficient quality to perform an X-ray structural analysis which were grown from hexane/ether solution. Fig. 1 shows the molecular structure of $(E)-\mathbf{4}$, and the crystal data and structure refinement are summarized in Table 1. The crystallographic characteristics found are similar to those of the classical hydroxytamoxifen-like structures [11]. As in the case of the ferrocifens [5b], the rate of isomerization of $\mathbf{4}$ depends on the nature of solvent; neither isomer showed isomerization after a week in DMSO. 


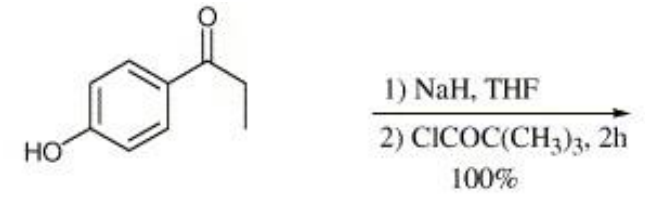<smiles>CCC(=O)c1ccc(OP)cc1</smiles><smiles>CC(C)=O</smiles>
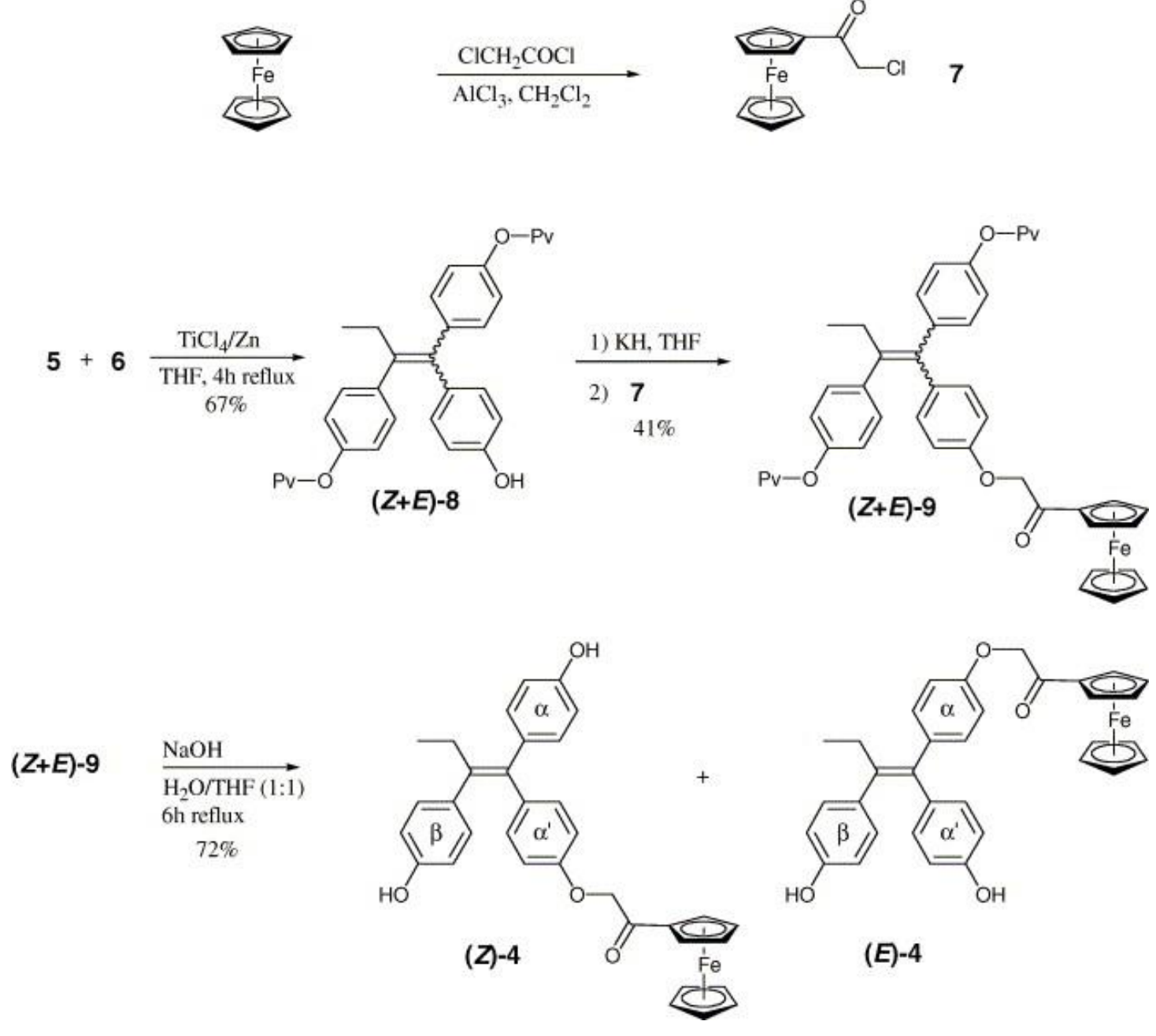

Scheme 1. Synthetic pathway to ferrocenyl derivatives (Z)-4 and (E)-4. 


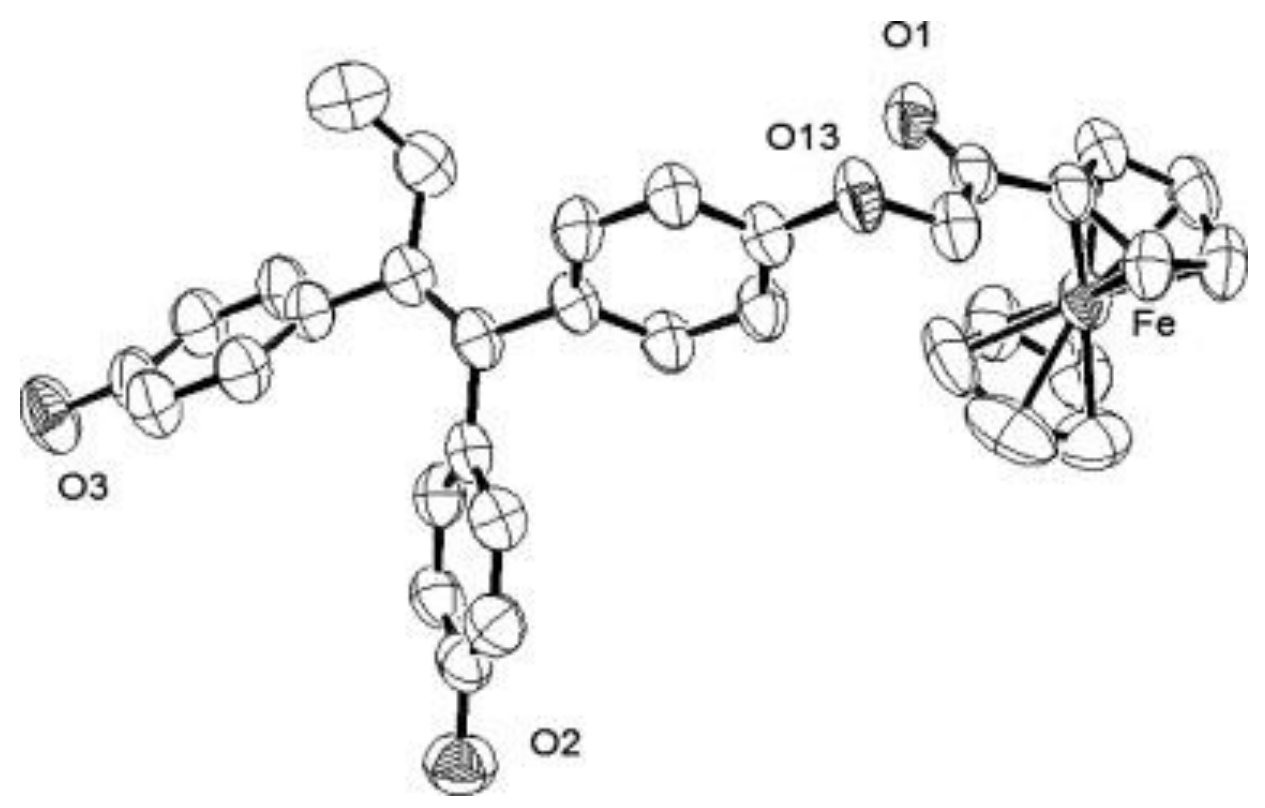

Fig. 1. ORTEP diagram of compound (E)-4. Thermal ellipsoids shown at 50\% probability. Minor part of the disordered (unsubstituted) $\mathrm{Cp}$ ring, the diethyl ether solvent molecule, and hydrogen atoms omitted for clarity.

Table 1. Crystal data and structure refinement for compound $(E)-4 \cdot 0.5\left(\mathrm{C}_{4} \mathrm{H}_{10} \mathrm{O}\right)$

Empirical formula

Formula weight

Crystal System

Space group

Unit cell dimensions

$a(\AA)$

$b(\AA)$

$c(\AA)$

$\alpha\left(^{\circ}\right)$

$\beta\left({ }^{\circ}\right)$

$\gamma\left({ }^{\circ}\right)$

Volume $\left(\AA^{3}\right)$

$Z$

Calculated density $\left(\mathrm{g} / \mathrm{cm}^{3}\right)$

Crystal size (mm)
$\mathrm{C}_{36} \mathrm{H}_{35} \mathrm{FeO}_{4.50}$

587.521

Triclinic

$P \overline{1}$

10.6911(1)

13.5700(3)

13.7129(1)

68.664(1)

84.440(1)

68.520(1)

1722.87(4)

2

1.148

$0.40 \times 0.28 \times 0.14$ 
Absorption coefficient $\left(\mathrm{mm}^{-1}\right)$

0.473

$F\left(\begin{array}{lll}0 & 0 & 0\end{array}\right)$

626

Wavelength $(\AA)$

0.71073

Orientation reflections, number, range $(\theta)$

$4301,1.60-29.86$

$\theta$ Range for data collection

$1.60-24.00$

Reflections collected

8530

Independent reflections

$5365\left[R_{\text {int }}=0.0286\right]$

Data/restraints/parameters

$5365 / 30 / 396$

Refinement method

Full-matrix least-squares on $F^{2}$

Final $R$ indices $[I>2 \sigma(I)]$

$R 1=0.0640, w R 2=0.1640$

$R$ Indices (all data)

$R 1=0.0895, w R 2=0.1803$

Goodness-of-fit on $F^{2}$

0.939

Largest peak and hole $\left(\mathrm{e} / \AA^{3}\right)$

0.76 and -0.32

\subsection{Receptor interactions}

The relative binding affinity (RBA) of $\mathbf{4}$ was determined by competitive binding with radiolabeled $\left[{ }^{3} \mathrm{H}\right]$ estradiol on both isoforms of the estrogen receptor (ER $\alpha$ and ER $\beta$ ), as previously described [5b]. Estradiol, natural hormone, is used as the reference, and therefore has a RBA of $100 \%$. The results are summarized in Table 2.

Table 2. Relative binding affinity of (Z)-4 and (E)-4 with the estrogen receptors (in DMSO, at $0{ }^{\circ} \mathrm{C}$, for $3 \mathrm{~h} 30$ ) measured as described in Ref. [8]

\begin{tabular}{|c|c|c|}
\hline \multirow{2}{*}{ Compound } & \multicolumn{2}{|c|}{ RBA (\%) } \\
\hline & ERa & $\mathbf{E R} \boldsymbol{\beta}$ \\
\hline $17 \beta$ Estradiol & 100 & 100 \\
\hline Hydroxytamoxifen $(Z+E)$ & 38.5 & 18.5 \\
\hline$(Z)-4$ & 13.9 & 12.8 \\
\hline$(E)-4$ & 1.2 & 1.6 \\
\hline
\end{tabular}


The (Z)-isomer of 4 well recognizes both the ER $\alpha$ and ER $\beta$ isoforms of the estrogen receptor (13.9\% and $12.8 \%$ respectively). The change in configuration of 4 from $(Z)$ to $(E)$ results in a dramatic drop in the affinity with both receptor isoforms $(1.2 \%$ and $1.6 \%)$. This is in agreement with previous results on tamoxifen, ferrocifens and other triarylethylenes: the estrogen receptor has a preference for the $(Z)$-isomer over the $(E)$-isomer [4b,5b].

In order to better understand these binding affinities, molecular modeling on $(E)-\mathbf{4}$ and $(Z)-\mathbf{4}$ in the antiestrogenic form of the estrogen receptor was investigated. We used the LBD structure (Protein Data Bank (PDB) code: 3ERT), published by Shiau [2], and MacSpartan Pro Software [12]. 4-Hydroxytamoxifen (OH-Tam) was removed and replaced successively by the two isomers $(E)$ and (Z)-4 (Fig. 2). An energy minimization routine was carried out with all the heavy atoms immobilized, except for those of the ligand and the His 524 side chain, using the Merck molecular force field (MMFF). A conformational study in the cavity was also carried out to determine the best position for the organometallic moiety in relation to the rest of the molecule and by taking into account that there is possibly a hydrogen bonding interaction both between Asp 351 and the iron atom, as Fe of the ferrocenyl side chain bears a slight negative charge (Mulliken charge $\approx-0.2$ ), or between Asp 351 and the carbonyl group adjacent to the ferrocenyl moiety. The affinity of the bioligand for the cavity was also determined using MMFF molecular mechanics, with calculations for the bioligand-cavity combination, and for the cavity and the bioligand done separately, each retaining the conformation previously determined for the molecular complex. This gives a value of the energy variation $\Delta E$ of the reaction: ligand + cavity $\rightarrow$ ligand-cavity complex. The cavity containing the amino side chain is large enough to host the bulky carbonylferrocenyl group. The energy variation $\Delta E$ found for $(Z)-4$ is $-106 \mathrm{kcal} \mathrm{mol}^{-1}$ if we consider a direct interaction between Asp 351 and $\mathrm{C}=\mathrm{O}$, and $-89 \mathrm{kcal} \mathrm{mol}^{-1}$ with a direct interaction between Asp 351 and Fe. Either way, those exothermic values favor association. The [(Z)-4]-cavity complex is twice as stable as that of the $[(E)-4]$-cavity according to molecular modeling study which yielded a value for $[(E)-4]$-cavity of $-58 \mathrm{kcal} \mathrm{mol}^{-1} \mathrm{~s}$ (in case Asp 351 interacts with $\mathrm{CO}$ ) and $-45 \mathrm{kcal} \mathrm{mol}^{-1}$ (in case Asp 351 interacts with Fe). This is consistent with the observed loss of affinity for the estrogen receptor of the $(E)$-isomer as compared to its $(Z)$ counterpart. 

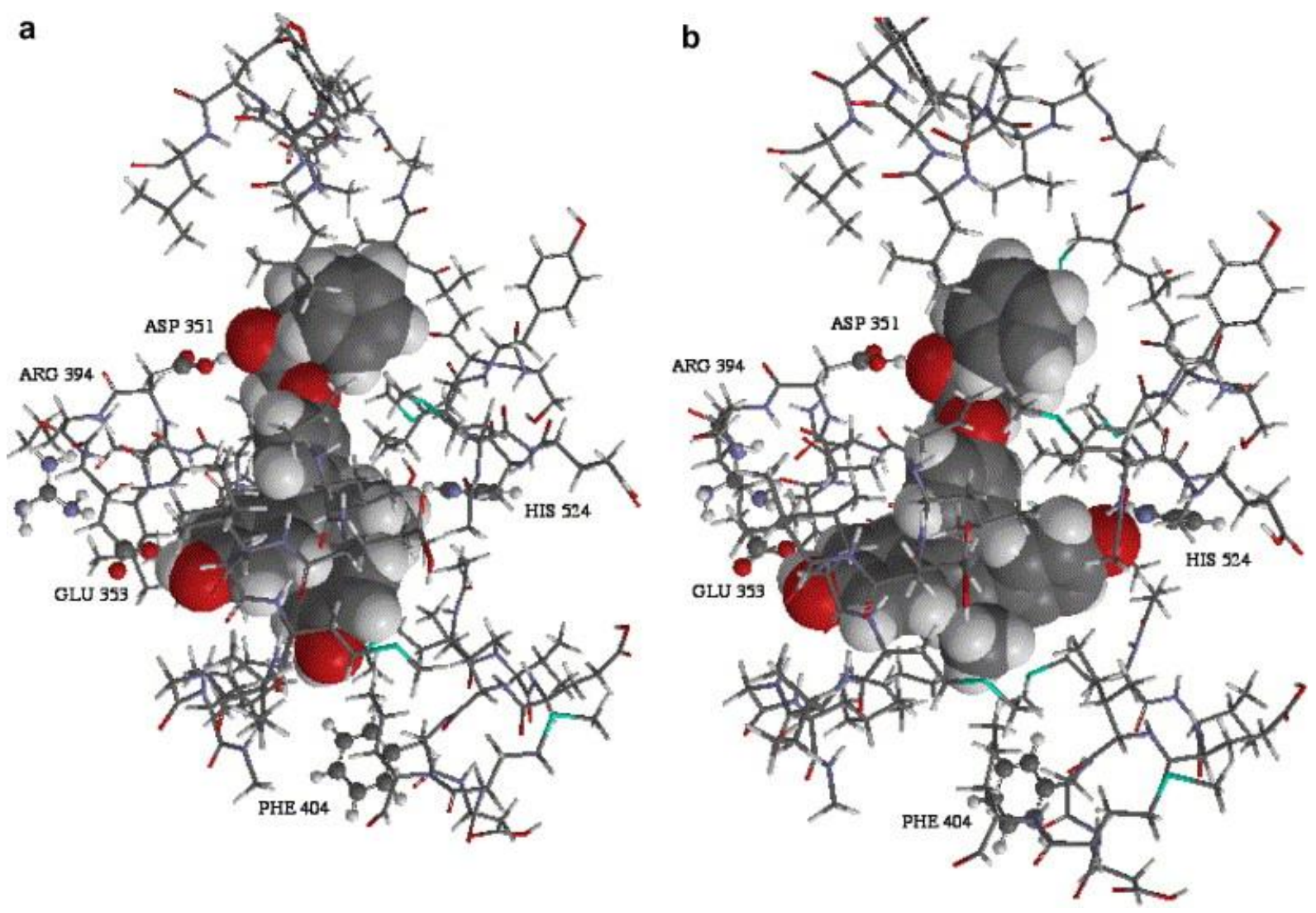

Fig. 2. Representations of (a) (E)-4 and (b) (Z)-4 docked in ER $\alpha$, assuming a direct interaction between the carbonyl group of $\mathbf{4}$ with Asp 351.

\subsection{Antiproliferative effects}

The antiproliferative effects of (Z)-4 and (E)-4 were studied on hormone-dependent MCF-7 cells, derived from a breast cancer line containing the estrogen receptor (ER+), and on hormone-independent PC-3 prostate cancer cells, as described previously [6]. Both diastereoisomers have similar antiproliferative activity, with an average $\mathrm{IC}_{50}$ value of $10.4 \mu \mathrm{M}$ on MCF-7 cells and $8.9 \mu \mathrm{M}$ on PC-3 cells. This is better than cis-platin (16.7 $\mu \mathrm{M}$ on MCF-7) [13]. However, it is not as strong as that of the ferrocifens $\left(n=3: \mathrm{IC}_{50}=0.5 \mu \mathrm{M}\right)$, or the ferrocenyl diphenol $10\left(\mathrm{IC}_{50}=0.7 \mu \mathrm{M}\right)$ (Chart 2) [5b,7]. The antiproliferative activity of 4 may be due either to an antihormonal mechanism, or to the cytotoxic character of the ferrocenyl group. 


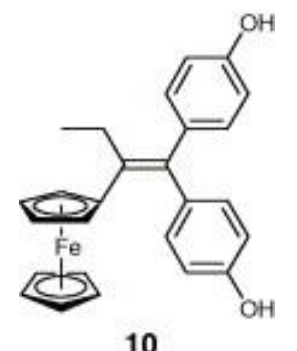

10

Chart 2. Ferrocenyl diphenol 10.

According to the antiproliferative test results, although there is probably a ligand-receptor interaction occurring, the bulky carbonylferrocenyl group might not be basic enough to strongly interact with Asp 351, as observed with the amino group of the hydroxytamoxifen [3a]. Since this interaction is required to produce an efficient antihormonal effect, it may explain the weaker antiproliferative activity of $\mathbf{4}$ than that of hydroxytamoxifen.

On the other hand, the cytotoxic character of the ferrocenyl group could also be responsible for the antiproliferative activity of 4. This hypothesis is supported by the observed antiproliferative effect of $\mathbf{4}$ on prostate PC-3 cancer cells, which lack ER $\alpha$. This mechanism, illustrated by the ferrocenyl diphenol $\mathbf{1 0}$ and the ferrocifens, may be based on the generation of a cytotoxic quinone methide, assisted by the ferrocene moiety [7]. However, the electron carrier $\pi$-system "ferrocene-double bond-phenol" required for this mechanism is missing in 4. Therefore, the antiproliferative effect observed must follow another mechanism, which might involve ferricinium ion and hydroxyl radicals via the Fenton process [14,6].

\section{Conclusions}

In summary, for the first time, an organometallic moiety has replaced the amino side chain of hydroxytamoxifen. The substitution did not greatly disrupt the interaction of the ligand with the estrogen receptor $\alpha$, as shown in the molecular modeling studies; and the relative binding affinity tests with the receptor confirm the good affinity of these compounds. Compound 4 exhibits an anti-proliferative activity on the hormone-dependent MCF-7 breast cancer cells, and on the ER negative prostate PC-3 cancer cells. Moreover, it has been shown that ferrocenyl derivatives can be used as stable precursors of rhenium and technetium derivatives in the double ligand-transfer reaction [15]. We found that $\mathbf{4}$ can indeed be transformed into 
technetium and rhenium analogues. Thus, 4 may be very useful in the synthesis of new radiopharmaceuticals. This study is now under way.

\section{Experimental}

4.1. $(Z+E) 9$

In a Schlenk tube, under inert atmosphere, $\mathrm{KH}$ dispersed at $25-35 \%$ in oil $(0.03 \mathrm{~mL}$, $1.2 \mathrm{mmol}, 1.2$ equiv.) was added in $10 \mathrm{~mL}$ of anhydrous THF. After stirring for $5 \mathrm{~min}$, a red solution 1-(p-hydroxyphenyl)-1,2-di(p-trimethylacetoxyphenyl)but-1-ene $\quad(8) \quad(500 \mathrm{mg}$, $1 \mathrm{mmol}, 1$ equiv.) in $10 \mathrm{~mL}$ of anhydrous THF was added. The mixture was stirred under reflux for $25 \mathrm{~min}$. The (1,2-chlorooxoethyl)ferrocene (7) (348 mg, $1.3 \mathrm{mmol}, 1.3$ equiv.) in $10 \mathrm{~mL}$ of anhydrous THF was finally added. The solution was heated under reflux for $24 \mathrm{~h}$. The reaction mixture was hydrolyzed and extracted with dichloromethane, the organic phase was washed with water, dried over $\mathrm{MgSO}_{4}$, filtered, and the solvent removed under reduced pressure. By flash chromatography, an orange solid 9 (300 mg, 41\% yield) was obtained.

\section{2. (Z)-4 and (E)-4}

Compound 9 (220 mg, $0.3 \mathrm{mmol}$ ) was dissolved in $5 \mathrm{~mL}$ of THF. NaOH (220 mg, excess) in $5 \mathrm{~mL}$ of water was added. The mixture was allowed to stir under reflux for $6 \mathrm{~h}$. The reaction mixture was hydrolyzed and extracted with dichloromethane, the organic phase was washed with water, dried over $\mathrm{MgSO}_{4}$, filtered, and the solvent removed under reduced pressure. By flash chromatography, an orange-red solid 4 (120 mg, 72\% yield) was isolated as a mixture of $Z$ and $E$ isomers. MS (EI): $m / z=558[\mathrm{M}]^{+}, 121[\mathrm{CpFe}]^{+}$. The two isomers were separated by preparative HPLC (Kromasil C18, MeCN: $\mathrm{H}_{2} \mathrm{O}$ 70:30). (Z)-Isomer. ${ }^{1} \mathrm{H}$ NMR $(400 \mathrm{MHz}$, DMSO- $d_{6}$ ): $\delta 0.83\left(\mathrm{t}, 3 \mathrm{H}, J=7.2 \mathrm{~Hz}, \mathrm{CH}_{3} \mathrm{CH}_{2}\right.$ ), 2.35 (q, $2 \mathrm{H}, J=7.2 \mathrm{~Hz}, \mathrm{CH}_{3} \mathrm{CH}_{2}$ ), 4.23 (s, $5 \mathrm{H}, \mathrm{Cp}), 4.61$ (t, $2 \mathrm{H}, \mathrm{H} \beta$ of $\mathrm{C}_{5} \mathrm{H}_{4}$ ), 4.88 (t, $\mathrm{H} \alpha$ of $\left.\mathrm{C}_{5} \mathrm{H}_{4}\right), 5.04$ (s, 2H, O-CH $-\mathrm{CO}$ ), 6.40 and $6.59\left(\mathrm{~d}, \mathrm{~d}, 2 \mathrm{H}, 2 \mathrm{H}, J=8.4 \mathrm{~Hz}, \alpha^{\prime}-\mathrm{C}_{6} \mathrm{H}_{4}\right), 6.54$ and $6.87\left(\mathrm{~d}, \mathrm{~d}, 2 \mathrm{H}, 2 \mathrm{H}, J=8.2 \mathrm{~Hz}, \beta-\mathrm{C}_{6} \mathrm{H}_{4}\right)$, 6.95 and $7.06\left(\mathrm{~d}, \mathrm{~d}, 2 \mathrm{H}, 2 \mathrm{H}, J=8.4 \mathrm{~Hz}, \alpha-\mathrm{C}_{6} \mathrm{H}_{4}\right), 9.14$ and $9.20(\mathrm{~s}, \mathrm{~s}, 1 \mathrm{H}, 1 \mathrm{H}, \mathrm{OH}) .{ }^{13} \mathrm{C} \mathrm{NMR}$ (75.4 MHz, DMSO- $\left.d_{6}\right): \delta 13.5\left(\mathrm{CH}_{3} \mathrm{CH}_{2}\right), 28.5\left(\mathrm{CH}_{3} \mathrm{CH}_{2}\right), 68.8\left(\mathrm{C}_{5} \mathrm{H}_{4}\right), 69.7(\mathrm{Cp}), 70.0(\mathrm{O}-$ $\left.\mathrm{CH}_{2}-\mathrm{CO}\right), 72.3\left(\mathrm{C}_{5} \mathrm{H}_{4}\right), 75.9\left(\mathrm{C}_{i p}, \mathrm{C}_{5} \mathrm{H}_{4}\right), 113.6,114.8,114.9,130.1,130.3,131.3(\mathrm{CH}$ of $\left.3 \mathrm{C}_{6} \mathrm{H}_{4}\right), 132.3,134.2,136.3,136.7,139.9\left(3 \mathrm{Cq}\right.$ of $\mathrm{C}_{6} \mathrm{H}_{4}$ and $\left.\mathrm{C}=\mathrm{C}\right), 155.4,155.7,155.9(3 \mathrm{Cq}$ of $\left.\mathrm{C}_{6} \mathrm{H}_{4}\right), 198.4(\mathrm{CO})$. IR ( $\left.\mathrm{KBr}\right): 1663 \mathrm{~cm}^{-1}$ (CO). Anal. Calc. for $\mathrm{C}_{34} \mathrm{H}_{30} \mathrm{O}_{4} \mathrm{Fe}: \mathrm{C}, 72.54 ; \mathrm{H}$, 5.88. Found: C, 72.71; H, 5.58\%. (E)-Isomer. ${ }^{1} \mathrm{H}$ NMR (400 MHz, DMSO- $\left.d_{6}\right): \delta 0.81(\mathrm{t}, 3 \mathrm{H}$, $\left.J=7.2 \mathrm{~Hz}, \mathrm{CH}_{3} \mathrm{CH}_{2}\right), 2.33\left(\mathrm{q}, 2 \mathrm{H}, J=7.2 \mathrm{~Hz}, \mathrm{CH}_{3} \mathrm{CH}_{2}\right), 4.28(\mathrm{~s}, 5 \mathrm{H}, \mathrm{Cp}), 4.65$ (t, $2 \mathrm{H}, \mathrm{H} \beta$ of 
$\left.\mathrm{C}_{5} \mathrm{H}_{4}\right), 4.94\left(\mathrm{t}, \mathrm{H \alpha}\right.$ of $\left.\mathrm{C}_{5} \mathrm{H}_{4}\right), 5.19\left(\mathrm{~s}, 2 \mathrm{H}, \mathrm{O}-\mathrm{CH}_{2}-\mathrm{CO}\right), 6.40$ and $6.59(\mathrm{~d}, \mathrm{~d}, 2 \mathrm{H}, 2 \mathrm{H}$, $\left.J=8.4 \mathrm{~Hz}, \alpha^{\prime}-\mathrm{C}_{6} \mathrm{H}_{4}\right), 6.54$ and $6.87\left(\mathrm{~d}, \mathrm{~d}, 2 \mathrm{H}, 2 \mathrm{H}, J=8.2 \mathrm{~Hz}, \beta-\mathrm{C}_{6} \mathrm{H}_{4}\right), 6.95$ and $7.06(\mathrm{~d}, \mathrm{~d}$, $\left.2 \mathrm{H}, 2 \mathrm{H}, J=8.4 \mathrm{~Hz}, \alpha-\mathrm{C}_{6} \mathrm{H}_{4}\right), 9.14$ and 9.20 (s, s, $\left.1 \mathrm{H}, 1 \mathrm{H}, \mathrm{OH}\right) .{ }^{13} \mathrm{C}$ NMR $(75.4 \mathrm{MHz}, \mathrm{DMSO}-$ $\left.d_{6}\right): \delta 13.5\left(\mathrm{CH}_{3} \mathrm{CH}_{2}\right), 28.3\left(\mathrm{CH}_{3} \mathrm{CH}_{2}\right), 68.8\left(\mathrm{C}_{5} \mathrm{H}_{4}\right), 69.8(\mathrm{Cp}), 70.2\left(\mathrm{O}-\mathrm{CH}_{2}-\mathrm{CO}\right), 72.3$ $\left(\mathrm{C}_{5} \mathrm{H}_{4}\right), 75.9\left(\mathrm{C}_{i p}, \mathrm{C}_{5} \mathrm{H}_{4}\right), 114.4,114.4,114.7,130.0,130.3,131.3\left(\mathrm{CH}\right.$ of $\left.3 \mathrm{C}_{6} \mathrm{H}_{4}\right), 132.5$, 133.9, 136.6, 140.0 (3Cq of $\mathrm{C}_{6} \mathrm{H}_{4}$ and $\mathrm{C}=\mathrm{C}$ ), 155.0, 155.2, 156.6 (3Cq of $\left.\mathrm{C}_{6} \mathrm{H}_{4}\right), 198.5(\mathrm{CO})$.

IR (KBr) : $1665 \mathrm{~cm}^{-1}$ (CO). Anal. Calc. for $\mathrm{C}_{34} \mathrm{H}_{30} \mathrm{O}_{4} \mathrm{Fe}: \mathrm{C}, 72.54 ; \mathrm{H}, 5.88$. Found: $\mathrm{C}, 72.48$; $\mathrm{H}, 5.53 \%$.

\subsection{Crystal data for $(\mathrm{E})-\mathbf{4} \cdot 0.5\left(\mathrm{C}_{4} \mathrm{H}_{10} \mathrm{O}\right)$}

A single crystal was attached to a glass fiber mounted on the Bruker SMART system for data collection using Mo Ka radiation at $296 \mathrm{~K}$. Cell parameters were obtained from the autoindexing routine SMART [16] and were refined with 4301 reflections within a $2 \theta$ range of $3.20-59.72^{\circ}$. Data reduction and integration were performed with the software package SAINTPLUS [17]. Absorption corrections were applied using the program SADABS [18]. Crystal and space group symmetries were determined using the XPREP program [19]. The positions of some of the non-hydrogen atoms were found by direct methods using the program SHELXS [20]. The positions of the remaining non-hydrogen atoms were located by use of a combination of least-squares refinement and difference Fourier maps in the SHELXL-97 [21] program. Non-hydrogen atoms were refined with anisotropic displacement parameters. The hydrogen atoms were included in the structure factor calculations at idealized positions. The diethylether solvent molecule was disordered over the inversion centre, and thus the occupancy was fixed at 0.5 . The unsubstituted cyclopentadienyl ring was disordered over two rotational positions. These were modeled as rigid pentagons with a major part occupancy of $80 \%$.

\section{Supplementary material}

CCDC 626320 contains the supplementary crystallographic data for this paper. These data can be obtained free of charge via http://www.ccdc.cam.ac.uk/conts/retrieving.html, or from the Cambridge Crystallographic Data Centre, 12 Union Road, Cambridge CB2 1EZ, UK; fax: (+44) 1223-336-033; or e-mail: deposit@ccdc.cam.ac.uk. 


\section{Acknowledgments}

We thank the Ministère de la Recherche and the Centre National de la Recherche Scientifique for financial support, A. Cordaville, M.-A. Plamont and Dr. X. Wang for technical assistance, M.-N. Rager for 2D-NMR experiments, and Dr. J. Marrot for collecting the crystallographic data.

\section{References}

[1] (a) C.V. Jordan, J. Med. Chem. 46 (2003) 883, and 1081;

(b) J. Lewis, C.V. Jordan, Mutat. Res. 591 (2005) 247;

(c) R.A. Magarian, L.B. Overacre, S. Singh, K.L. Meyer, Curr. Med. Chem. 1 (1994) 61

(d) D.G. Lloyd, R.B. Hughes, D.M. Zisterer, D.C. Williams, C. Fattorusso, B. Catalanotti, G. Campiani, M.J. Meegan, J. Med. Chem. 47 (2004) 5612.

[2] A.K. Shiau, D. Barstad, P.M. Loria, I. Cheng, P.J. Kushner, D.A. Agard, G.I. Greene, Cell 95 (1998) 927.

[3] (a) V. Agouridas, I. Laïos, A. Cleeren, E. Kizilian, E. Magnier, J.-C. Blazejewski, G. Leclercq, Bioorg. Med. Chem. 14 (2006) 7531;

(b) A.B. Foster, R. MacCague, A. Seago, G. Leclercq, S. Stoessel, F. Roy, AntiCancer Drug Des. 1 (1986) 245;

(c) D. Robertson, J.A. Katzenellenbogen, J.R. Hayes, B.S. Katzenellenbogen, J. Med. Chem. 25 (1982) 167.

[4] (a) V.N. Rubin, P.C. Ruenitz, J.L. Boyd, F.D. Boudinot, T.E. Wiese, Biochem. Pharmacol. 63 (2002) 1517;

(b) K.S. Kraft, P.C. Ruenitz, M.G. Bartlett, J. Med. Chem. 42 (1999) 3126;

(c) T.M. Willson, B.R. Henke, T.M. Momtahen, P.S. Charifson, K.W. Batchelor, D.B. Lubahn, L.B. Moore, B.B. Olivier, H.R. Sauls, J.A. Triantafillou, S.G. Wolfe, P.G. Baer, J. Med. Chem. 37 (1994) 1550. 
[5] (a) S. Top, A. Vessières, C. Cabestaing, I. Laios, G. Leclercq, C. Provot, G. Jaouen, J. Organomet. Chem. 637-639 (2001) 500;

(b) S. Top, A. Vessières, G. Leclercq, J. Quivy, J. Tang, J. Vaissermann, M. Huché, G. Jaouen, Chem. Eur. J. 9 (2003) 5223;

(c) G. Jaouen, S. Top, A. Vessières, G. Leclercq, M.J. McGlinchey, Curr. Med. Chem. 11 (2004) 2505.

[6] E. Hillard, A. Vessières, F. Le Bideau, D. Plazuk, D. Spera, M. Huché, G. Jaouen, Chem. Med. Chem. 1 (2006) 551

[7] (a) E. Hillard, A. Vessières, L. Thouin, G. Jaouen, A. Amatore, Angew. Chem., Int. Ed. 45 (2006) 285;

(b) A. Vessières, S. Top, P. Pigeon, E. Hillard, L. Boubekeur, D. Spera, G. Jaouen, J. Med. Chem. 48 (2005) 3937.

[8] A. Vessières, D. Spera, S. Top, B. Misterkiewicz, J.M. Heldt, E.A. Hillard, M. Huché, M.A. Plamont, E. Napolitano, R. Fiaschi, G. Jaouen, Chem. Med. Chem. 1 (2006) 1275-1281.

[9] S. Top, B. Dauer, J. Vaissermann, G. Jaouen, J. Organomet. Chem. 541 (1997) 355361.

[10] S. Gauthier, J. Mailhot, F. Labrie, J. Org. Chem. (1996) 3890.

[11] (a) B.T. Kilbourn, P.G. Owston, J. Chem. Soc. B26 (1970) 1;

(b) G. Precigoux, C. Courseille, S. Geoffe, M. Hospital, Acta Crystallogr., Sect. B 35 (1979) 3070.

[12] MacSpartan Pro, Odyssey Wavefunction Society, 18401 Von Karman Avenue, Irvine, CA 92612, USA.

[13] C. Descôtaux, J. Ptovencher-Manderville, I. Mathieu, V. Perron, S.K. Mandal, E. Asselin, G. Bérubé, Bioorg. Med. Chem. Lett. 13 (2003) 3927.

[14] (a) A.M. Joy, D.M.L. Goodgame, J. Stratford, Int. J. Radiat. Oncol. Biol. Phys. 16 (1989) 1053;

(b) H. Tamura, M. Miwa, Chem. Lett. 11 (1997) 1177; 
(c) D. Osella, M. Ferrali, P. Zanello, F. Laschi, M. Fontani, C. Nervi, G. Cavigiolio, Inorg. Chim. Acta 306 (2000) 42;

(d) G. Tabbi, C. Cassino, G. Cavigiolio, D. Colangelo, A. Ghilia, I. Viano, D. Osella, J. Med. Chem. 45 (2002) 5786.

[15] S. Masi, S. Top, L. Boubekeur, G. Jaouen, S. Mundwiler, B. Spingler, R. Alberto, Eur. J. Inorg. Chem. (2004) 2013.

[16] SMART for Windows NT, Bruker AXS Inc., Madison, WI, 1997-2001.

[17] SAINTPLUS for NT, Bruker AXS Inc., Madison, WI, 1997-2001.

[18] SADABS, V2.03, Bruker/Siemens Area Detector Absorption and Other Corrections, Bruker AXS Inc., Madison, WI, 2000.

[19] XPREP, Bruker AXS Inc., Madison, WI, 1997-2001.

[20] G.M. Sheldrick, SHELXS-97: Program for Crystal Structure Solution, University of Göttingen, Göttingen, Germany, 1986-1997.

[21] G.M. Sheldrick, SHELXL-97: Program for Crystal Structure Refinement, University of Göttingen, Göttingen, Germany, 1997. 